\title{
Birds of the Mongol Empire
}

\author{
Eugene N. Anderson ${ }^{1 *}$ \\ ${ }^{1}$ Department of Anthropology, University of California, Riverside, USA. \\ *eugene.anderson@ucr.edu
}

\begin{abstract}
The Mongol Empire, the largest contiguous empire the world has ever known, had, among other things, a goodly number of falconers, poultry raisers, birdcatchers, cooks, and other experts on various aspects of birding. We have records of this, largely in the Yinshan Zhengyao, the court nutrition manual of the Mongol empire in China (the Yuan Dynasty). It discusses in some detail 22 bird taxa, from swans to chickens. The Huihui Yaofang, a medical encyclopedia, lists ten taxa used medicinally. Marco Polo also made notes on Mongol bird use. There are a few other records. This allows us to draw conclusions about Mongol ornithology, which apparently was sophisticated and detailed.
\end{abstract}

Received June 6, 2016

OPEN ӘACCESS

Accepted July 7, 2016

DOI 10.14237/ebl.7.1.2016.715

Keywords Ethnoornithology, Mongol empire, Falconry, Zoomedicine, Medieval Asia

Copyright (C) 2016 by the author(s); licensee Society of Ethnobiology. This is an open-access article distributed under the terms of the Creative Commons Attribution-NonCommercial 4.0 International Public License (https://creativecommons.org/licenses/by-nc/4.0), which permits non-commercial use, distribution, and reproduction in any medium, provided the original author and source are credited.

This paper introduces the ornithological world of the Mongol Empire. We have only a few sources for knowledge of Mongol Empire ethnoornithology, but fortunately they are revealing and interesting. They cover two areas: hunting, specifically falconry, and medicine. Birds were used both to hunt and as game. When caught, they often became food, and were then evaluated in terms of the nutritional science of the age. Significantly, these two fields-hunting and medicine-were not only fully scientific by the $13^{\text {th }}$ century, but were subjects of major scholarly research and writing. Presumably, farmers and country folk knew as much about wild and tame birds, including keeping fowl, but their knowledge is largely lost to us.

\section{Marco Polo and Falcons}

Let us begin, as students of medieval Mongolia always seem to do, with Marco Polo. His travels through central Asia and China are uniquely well recorded, but not unique; thousands of merchants thronged the silk routes of central Asia in the Mongol period. The Mongol empire established peace throughout this vast realm. "Indeed, it was said a virgin carrying a gold urn filled with jewels could walk from one end of the empire to another without being molested" (May 2012:109); a stock exaggeration, but indicating some real feeling about the time.
Marco Polo differs from other travelers in that his story was recorded (not by him, but by one Rusticello, hence some distortions in the final tale). Polo was a talented observer, and his words about birds are worth repeating.

Above all, bird activities in central Asia of that age meant falconry. Among the "Tartars," for instance: "The women do the buying and selling, and whatever is necessary to provide for the husband and household; for the men all lead the life of gentlemen, troubling themselves about nothing but hunting and hawking, and looking after their goshawks and falcons..." (Polo 1927:81). In Shangdu, the summer capital that Samuel Taylor Coleridge immortalized under the Portuguese spelling of Xanadu, there were "more than 200 gerfalcons [Falco rusticolus] alone, without reckoning the other hawks" (Polo 1927:94).

When the Emperor "goes thus a-fowling with his gerfalcons and other hawks, he is attended by full 10,000 men who are disposed in couples.... Every man of them is provided with a whistle and hood, so as to be able to call in a hawk and hold it in his hand" (Polo 1927:130). "There are also a great number of eagles, all broken to catch wolves, foxes, deer, and wild goats, and they do catch them in great numbers. But those especially that are trained to wolf- 
catching are very large and powerful birds, and no wolf is able to get away from them" (Polo 1927:128). Falconry with golden eagles (Aquila chrysaetos) is still a fairly common practice in eastern Mongolia and neighboring areas, largely among Kirghiz and $\mathrm{Ka}-$ zakhs. Apparently the many other species of eagles found in that area are not used, since the goldens are in nature more specialized as large-mammal hunters.

Polo (1927:93) makes many other references to hawking and to game birds. For instance, at Chagannor (White Lake) in Mongolia: "The...plains... abound with cranes, partridges, pheasants, and other game birds... There are five different kinds of cranes found in those tracts, as I shall tell you. First, there is one which is very big, and all over as black as a crow [hooded crane, Grus monacha]; the second kind again is all white, and is the biggest of all; its wings are really beautiful, for they are adorned with round eyes like those of a peacock, but of a resplendent golden colour, whilst the head is red and black, on a white ground Japanese crane G. japonensis, the head pattern making the identification certain; probably including Siberian crane, G. leucogeranus, but it does not have the head pattern]. The third kind is the same as ours [Grus grus]. The fourth is a small kind, having at the ears beautiful long pendent feathers of red and black [demoiselle crane, Grus virgo, an excellent description of a bird still common in Mongolia]. The fifth kind is grey all over and of great size, with a handsome head, red and black [white-naped Crane, G. vipio]." This description alone should clinch the certainty that Marco Polo did make his journey. No one who had not seen these cranes often could possibly describe them so well. The only problem is that the wings of the Japanese crane do not have golden spots, but ironstaining from the acid bog water on the breeding grounds can account for that.

In that area was a valley where the Mongols raised captive cators, defined as like great partridges. These were sandgrouse (Syrrbaptes paradoxus), which are khata in Arabic, that term being very widely used for them in central Asia.

Polo has many other incidental notes on hawking and game birds, but nothing adds much more to the above accounts.

He heard of, but did not visit, lands north of Mongolia, including the Merkit country where people ride on reindeer. Still farther, there are "...the mountains...in which the Peregrine falcons have their nests. And in those mountains it is so cold that you find neither man nor woman, nor beast nor bird, except one kind of bird called Barguerlac, on which the falcons feed. They are as big as partridges, and have feet like those of parrots and a tail like a swallow's, and are very strong in flight" (Polo 1927:87-88). Of course there were dozens of species of birds eaten by Peregrines in northern Siberia, so the barguerlac must remain unidentified.

The emphasis on falconry in Marco Polo's description of Mongolian bird life reminds us that throughout Eurasia hunting was not only an obsession of the nobles and a livelihood of the poor, but also a science. The distinguished Mongolist Thomas Allsen has written a major book on the royal hunt (Allsen 2001), showing that it was a way of showing power and might, as well as training for war (Allsen 2006). The nobles maintained that it helped the peasants by eliminating wolves, bears, crop-eating herbivores, and other pests, but actually it deprived the peasants of game and above all of land. Millions of acres in Eurasia were tied up in hunting parks. China and Mongolia eliminated these over time, to the benefit of farmers but the detriment of wildlife.

Friar William of Rubruck in the mid-13 $3^{\text {th }}$ century also noted the falconry, but as a friar he was not concerned with it: "They have an abundance of gerfalcons... which they uniformly carry on the right hand" (Rubruck 1990:85).

\section{Falconry and the Hunt in Medieval Europe}

Falconry, and the ideal of the aristocrat as rider, hunter, and falconer, came to Europe from Central Asia. It came above all with the Huns, who famously harried the dying Roman Empire. They developed powerful states and ruled most of Europe during the fall of the Roman Empire. The great Germanic states such as Visigothic Spain and Frankish France owe everything to Hun conquests, organization, and intermarriage with Germanic dynasties (Kim 2016). Falconry spread accordingly.

After that, for the elite, hunting was life. An Elizabethan English work, The Institucion of a Gentleman (anon, 1568, quoted Almond 2003:33) puts it perfectly: "There is a saying among hunters that he cannot be a gentlemen [sic] which loveth not hawking and hunting, which I have heard old woodmen well allow as an approved sentence among them. The like saying is that he cannot be a gentleman which loveth not a dog." Certainly the Mongols love their dogs, not just as hunters but, much more, as livestock and home 
guardians. There is now a major movement in Mongolia to maintain the breed of the beautiful and friendly (though protective) Mongolian bankhar, a black-and-tan mastiff rather like a small Bernese mountain dog and probably related to it (Mongolian Bankhar Dog Project).

More to the point of the present paper, the level of scientific zoology that went into hunting seems absolutely incredible to anyone believing in the stereotypes of the "middle ages." Sadly, we have no major hunting texts from early Mongolia or China. But in the west, some survive (e.g. Edward of Norwich 2005 [a reprint of a 1909 edition of a book from ca. 1410], based heavily on a French work by Gaston Phébus, Count of Foix, from the 1390s). By far the most ornithologically impressive is Frederick II of Hohenstaufen's de Arte Venandi cum Avibus, translated as The Art of Falconry (Hohenstaufen 1943). This amazing work, written around 1250, is still in print in various languages, and I have been told that it is still actually used by falconers as a working text. It involves serious, methodical science as good as a great deal of modern research. Frederick tested theories, debunked old tales, and sought out information as a true scholar. He was not some isolated genius; his scientific work fits in with the Aristotelian science that became popular in the Middle East, and then in Italy in the early 1200s. It is no accident that Frederick was a close contemporary of Genghis Khan (1194-1250 and 1167-1227 respectively). One suspects that Genghis could have written a similar book, had he ever had time to sit and write.

Frederick would have been the last to maintain he worked in isolation. He dedicated his book, significantly, to a neighboring Muslim Sultan who was also a scholar of falconry. In fact, the information came from all parts of Eurasia. Falconry linked the British Isles and Japan into one great information and trade network. Gyrfalcons were particularly important as embodiments of contact. Produced only in the arctic, they were traded everywhere, as Marco Polo's account stated. The role of hunting and falconry in the development of science has never been adequately addressed (though see Almond 2003).

Falconry became familiar enough that it entered the language in a metaphoric sense. A fairly common scam in old China, and still today, was for a man to promise a woman to a desperate wife-seeker for a fancy marriage fee. When the marriage fee forthcomes, the man and the woman disappear and are not seen again. He has flown her like a falcon (fangying, "fly a hawk") and she has returned to his hand (see Sommer 2015:272-273).

\section{Birds in Mongol Zoomedicine}

We now turn to the other great science of the Medieval period: medicine. In China and Mongolia, food was critically important and malnutrition frequent, and thus nutritional science was the most important branch of medicine. Foods were evaluated according to their medicinal value. We thus have considerable information about the perceived medicinal values of birds.

Medicine had to be rational and scientific to have any value at all. In place of the preposterous nonsense found in popular accounts of the "middle ages," we find throughout Eurasia the dominance of the rational, enlightened, scholarly views of Hippocrates and Galen. They were not modern biomedicine, but they quite naturally evolved into it, because they were wholly naturalistic, thoughtful, and driven by careful observation under the guidance of theories that were progressively refined-in short, they were full-fledged science. They were not alone, however. They coexisted, and often blended, with many local traditions. Some of these were rational and scientific; many were, instead, highly personalistic theories based on belief in spirits, witches, wizards, evil winds, and other supernaturals.

In Mongolia, Hippocratic-Galenic medicine from the west combined in the medieval period with Chinese medicine coming from the east. Both were informed by local Mongolian practice, especially in the area of veterinary medicine and empirical zoology.

We have about one-sixth of a huge medical encyclopedia, the "West Asian Medicine and Formulary Book" (Huibui Yaofang), surviving from this period (Kong 1996; Song 2000). What is left tells us nothing about how birds were used, but very fortunately it does include a list of the birds and other medical substances that were used. Here is the list, as translated and identified by Dr. Paul Buell, who has translated what survives of the book:

The 19 birds mentioned in the Huibui Yaofang (from Song 2000:112-113, translation in progress by Paul Buell and E. N. Anderson), in order as in its Table of Contents (though there are, between "sandgrouse" and "peacock," several miscellaneous non-avian animals): 
- Male chicken and female chicken

- Duck

- Pigeon

- Swallow

- Francolin

- Goose, unknown species

- Quail

- Sparrow

- Sand grouse

- Peacock

- Crane

- Swan

- Adjutant [Leptoptilus javanicus in the Arabic used, but here surely meaning a Ciconia stork, which, unlike the adjutant, is native to central Asia]

- Xunbu [to smoke + bird; unidentified]

- Lapwing, Vanellus vanellus

- Ostrich

- Müghäli, "shrew mouse," presumably a kind of bat, since listed with birds, though "bat" is a separate category and put with the mammals

- Kite (or similar bird; general term)

- Vulture

Most of these are used today as strengthening or supplementing foods (bu pin) in Chinese medicine. Such foods are generally very high in protein and iron. While traditional Chinese doctors did not know modern chemistry, they did know the presenting symptoms of malnutrition of all types, and were perfectly familiar with wasting and weakness caused by lack of meat and, above all, with the symptoms of anemia: pallor, weakness, easy tiring, and pale or thin blood, and so on. They knew from experience which foods treated these conditions best-those we would now identify as rich in protein and iron. Among such foods, wild birds have pride of place.

Another and less biomedically confirmed characteristic of supplementing foods is that they should look weird or uncanny. If they were striking and impressive to Mongol and Chinese observers, the observers thought this meant that the foods in question had a great deal of powerful qi. Qi basically means breath or air, but it is extended to mean the life force or life energy that animates us all (as in qigong and similar phrases). If an animal, plant, or even rock looks very striking and weird to a human, that means that the $q i$ that animates it is particularly forceful and effective. Thus, big, powerful, strange-looking birds like cranes and vultures were considered to be very high in $q i$, and thus effective at supplementing the $q i$ of the eater. The birds in the list above are all of the sort now regarded as supplementing, and most are in current use as such; all are high in protein and iron, and the stork, ostrich, vulture, and kite are strange enough to be regarded as rich in the uncanny, spiritdense $q i$ that is associated with weirdness and is believed to be very strengthening. In Hong Kong in the long-ago 1960s and 1970s, I have seen kites and vultures sold in medicine markets for exactly that reason.

The other revealing text from the period is the Yinshan Zhengyao, or "Important Knowledge for Drinking and Feasting" (Buell et al. 2012). This was the court nutrition manual, edited by the court's head nutritionist, Hu Sihui, a Turkic-speaker from west China. The book was published in 1330, about the same time as the Huibui Yaofang. A large part of it is given over to descriptions of the medicinal value of the foods and herbs it mentions.

The birds mentioned in the Yinshan Zhengyao are under 24 taxa, each with a short description of its medical or nutraceutical value. Only eight of these are shared with the Huibui Yaofang list; the other 11 in that book are strictly medicinal, whereas the Yinshan Zhengyao is a book about foods.

Here is the Yinshan Zhengyao list (summarized from Buell et al. 2012):

- Greater golden-headed wildgoose (whooper swan, Cygnus cygnus; the golden head is due to iron staining from iron mobilized by acids in the boggy lakes loved by these birds; it is a familiar sight to American swan-watchers)

- Lesser golden-headed wildgoose (tundra swan, Cygnus columbianus)

- Mute swan (Cygnus olor)

- Variegated swan (immature mute swan)

- Chinese domestic goose (the Oriental swangoose, Anser cygnoides)

- Wildgoose (Anser spp.; "wildgoose" is one word and character in Chinese, not cognate with or related to the word for the tame goose)

- White crane (Grus japonicus, again probably including G. leucogeranus) 
- Black-headed crane (Grus nigocollis)

- Iranian crane (Grus grus)

- Eurasian curlew (shrija, identified today as Numenius arquata, but, from the illustration, evidently including other shorebirds and probably a general term for shorebirds)

- Chicken (Gallus gallus / Gallus domesticus; includes "food fowl" and "eared fowl")

- Pheasant ("wild chicken," Phasianus spp.)

- "Mountain chicken" (uncertain; name is a general one for many game birds; illustration shows something that could be a koklass pheasant, Pucrasia macrolopha, or a hazel hen Tetrastes bonasia, or something similar.

- Mallard (Anas platyrbynchos)

- Pintail (Anas acuta)

- Mandarin duck (Aix sponsa)

- Tufted duck (Aytbya fuligula)

- Pigeon (Columba livia)

- Dove (Streptopelia spp.)

- Great bustard (Otis tarda)

- Collared crow (Corvus torquatus)

- Common quail (Coturnix coturnix)

- Sparrow (Passer montanus and probably any similarsized bird)

- Bunting (Emberiza spp.)

Birds were evaluated in terms of the heating/ cooling medical system, identified with HippocraticGalenic medicine in the west and with the yin-yang system in the east; the two traditions had fused in China by this time. Hippocratic-Galenic medicine reached China by the A.D. 500s, and under the Mongols it was so well known that the abovementioned Huibui Yaofang actually claims (wrongly) that some of its formulas come from Galen himself. Birds that are heating are those that provide a lot of calories (body heat), or appear as if they should. Cooling birds are those that are small or lean and provide little caloric energy. Often, external signs were used, leading sometimes to wrong conclusions. For instance, spiciness or "hot" colors were taken to mean a food was heating; bland, "cool colored" foods were cooling.

Here is one of the fuller descriptions, the text on the swangoose: "Oriental swangoose [meat] is sweetish in flavor, neutral [neither hot nor cold], and lacks poison. It benefits the five viscera. It is good for diabetes. Meng Shen says: "the meat is chilling in nature. A lot should not be eaten. It causes obstinate illnesses.' The Ribuari says: 'the green Oriental swangoose: it is chilling in nature and has poison. If eaten it causes sores. The white swangoose lacks poison. Its [meat] counteracts the heat of the five viscera and stops thirst.' [Its] fat makes the skin sleek and is good for regulating deafness. [Its] droppings supplement the five viscera and augment $q i$. If one has an obstinate illness, too much should not be eaten" (Buell et al. 2012:515).

Another good description is of pheasant meat. It "is sweetish-sour in flavor, slightly cooling, and has a small amount of poison. It is good for supplementing the center and augments qi. It controls leaking diarrhea. If eaten for a long time it causes emaciation. If eaten from the ninth to the eleventh lunar months it will augment slightly. If eaten during other months it causes one to suffer from the five hemorrhoids and various sores. It also cannot be eaten with walnuts, Agaricus mushrooms, and tree ears" (Buell et al. 2012:518). Pheasant is still considered a supplementing, augmenting food.

The references to poison are not to toxin; some bird meats are believed to potentiate or bring out any poisons already in the system, and thus "have poison" in an indirect sense. As the great Li Shizhen says of goose: "I have witnessed cases of toxins being activated by the eating of goose meat" (Shizhen 2003:3725). I have very often encountered this belief today; people with cancer, for instance, avoid eating birds that "have poison," not because the birds are poisonous themselves but because they would somehow activate the cancer. People did not bother to avoid these nontoxic but poison-potentiating birds unless they had cancer or similar chronic conditions.

As is very often the case, doctors disagree about the qualities of foods, including most details about the goose; modern sources are even more varied. Most seem to agree that pheasants are cooling and have some poison (Shizhen 2003:3780-3783). Mandarin duck also has some poison-potentiating capability, as does "mountain chicken." The other birds lack poison-interesting in view of the modern belief that roosters are the most poison-potentiating of all foods.

The birds that are heating or warming are swan, crane, black chicken, "mountain chicken," quail, sparrow, and bunting. 
Neutral meats are swangoose, wildgoose, shorebirds, chicken except for black ones, mandarin duck, tufted duck, pigeon, dove, and bustard.

Cooling are pheasant and duck (domestic duck is downright chilling).

It can be safely assumed that farmers, herders, and country folk in general, in old Mongolia and China, knew far more. We have enough literary records to make it clear that they knew the species very clearly, with, usually, migration seasons, nesting data, conservation, uses (medicinal and otherwise), and all the other lore that rural people know about birds. Contemporary ethnography confirms this, if one can back-project modern knowledge, but there has been a surprising lack of ethnozoological work in northeast Asia (though see Roux [1966]; a few other sources, notably Arseniev [1996], have appreciable but scattered data).

Unfortunately, we have very little record of this. Country folk could not write, and aristocrats rarely did. Arab and Persian writers produced books on hunting and hawking, but these are not translated. Medicinal works add surprisingly little about birds to what is summarized above, though they have incredible amounts of data on herbs. Only the paintings and poetic accounts of birds survive to tantalize us. Paintings from China, Japan, central Asia and Persia in the Mongol period and for a few centuries after are often extremely exact ornithologically, making identification easy. Arthur de Carle Sowerby (1940) recorded over 55 species he identified in Chinese art, many of them well known in paintings and carvings by Mongol times. They fall into several wellrepresented categories: birds of prey, storks, cranes, herons, and pheasants. Dooryard birds like sparrows, mynas, and magpies are also common. The earlier paintings show clear direct observation-they were painted from life, or copied from paintings taken from life. Alas, after 1700 the bird paintings rapidly become less accurate, especially in urban areasmaking it sadly clear that China's environmental decline had by then reached a point at which few artists knew their birds from direct field observation.

\section{Conclusions on Mongolian-Bird Relationships}

Finally, the Mongolian attitude toward birds deserves to be noted. A Scottish missionary, James Gilmour (1970:217), observed, "not only do their cattle and flocks receive expressions of sympathy in suffering, and such alleviation of pain as their owner knows how to give; but even the meanest creatures, insects and reptiles included, are treated with consideration. One of the best proofs...is the tameness of the birds... Crows perch themselves on the top of loaded camels... hawks [black kites] sweep down in the market-place at Urga, and snatch eatables from the hands of the unwary.... and swallows, year after year, build their nests and rear their young inside the very tents of the Mongols." He adds that he discussed with a lama the fact that the swallows nesting in the latter's ger live by taking the lives of flies, and the lama replied: "they have no udders, they have nothing but flies to feed their young on, and what can they do? Hoarhe [alas!], dear little creatures" (Gilmour 1970: 265). The respect and compassion exhibited here fit perfectly with what I observed in Mongolia, and I quote it from another source partly to deflect any fears that I might be romanticizing; Gilmour hated Buddhism and animism and had no sympathy with their religious preference for not taking life.

The conclusion is that we have seriously misjudged and underestimated medieval science. Falconry and medicine were particularly well developed. Falconry, and ornithology, remain strikingly close to Frederick's Aristotelian approach. Medicine has changed its paradigm since then, with the discovery of microbes in the $19^{\text {th }}$ century, but Galenic medicine is still very much alive. It is not only a folk tradition; it has become embodied in modern biomedicine through its relentlessly secular, rational approach and its concern with diet, exercise, rest, and maintaining a good mood.

These sources I quote are the tiny tips of huge icebergs - the vast masses of empirical, constantly tested, experience-based, but often well theorized lore known to those who worked with hawks, hounds, herds, harts, hinds, and households, to say nothing of those who worked with fields, farms, foods, forests, and fresh waters, and those who worked with medicine, health, and healing. They kept alive the empirical and experimental approach that developed into modern science after Aristotlean methods spread widely in the 1100s and 1200s. We are in their debt every minute of our lives, but we almost never know their names. I have quoted before, and will surely quote many times again, the passage from Ecclesiasticus:

"Let us now praise famous men...

And some there be, which have no memorial; who are perished, as though they had never 
been; and are become as though they had never been born; and their children after them.

But these were merciful men, whose righteousness hath not been forgotten...

Their seed shall remain for ever, and their glory shall not be blotted out."

Ecclesiasticus 44:1, 8-13

\section{Appendix}

This is not to say that medieval zoology was all Aristotelian science. Far from it. Sadly typical of the other extreme of Mongol, and medieval, zoology is a story told to a European envoy to the Mongols, Giovanni di Plano Carpini. He was told that the Mongols once found a land with monstrous women and no visible men, because "whoever was born female had a human form, while the males had a dog's shape. When the Tartars prolonged their stay in this country, dogs in another part of a river gathered in one place, and even though it was a very cold winter they all threw themselves into the water. After this they rolled uncontrollably in the dust so that the dust mixed with the water and froze onto them. They would do this repeatedly so the ice formed over them densely and then they attacked the Tartars fiercely. When the Tartars shot arrows at them it was as if they shot against rocks: the arrows rebounded and in fact their other weapons could do them no damage either. The dogs however did the Tartars great harm and injured and killed many with bites and thus drove them from their borders..." (Plano Carpini 1996:61). Plano Carpini makes no secret of his skepticism about this. Clearly, travelers' tales, then as now, were not influenced by Aristotle's teachings on scientific accuracy. I have heard many equally fanciful stories all over the world, so let no one think that this sort of tall tale was peculiar to the middle ages.

\section{Acknowledgements}

Thanks very much to the EBL editorial team for careful editing.

\section{References Cited}

Allsen, T. 2001. Culture and Conquest in Mongol Eurasia. Cambridge University Press, Cambridge, MA.

Allsen, T. 2006. The Royal Hunt in Eurasian History. University of Pennsylvania Press, Philadelphia.

Almond, R. 2003. Medieval Hunting. Sutton Publishing, Gloucestershire.
Arseniev, V. K. 1996. Dersu the Trapper (Dersu Uzala). Malcolm Bur, trans. McPherson and Co, Kingston, NY.

Buell, P. D., E. N. Anderson, C. Perry. 2012. A Soup for the Qan, $2^{\text {nd }}$ edition. Brill, Lieden.

Gilmour, J. 1970. Among the Mongols. Praeger, New York.

Hohenstaufen, F. 1943. The Art of Falconry. Casey A. Wood and F. Marjorie Fyfe, trans. Stanford University Press, Stanford, CA.

Kim, H. J. 2016. The Huns. Routledge, London.

Kong, Y. C., ed. 1996. Huibui Yaofang. China Publishing House, Hong Kong.

May, T. 2012. The Mongol Conquests in World History. Reaktion Books, London.

Mongolian Bankhar Dog Project. Available at: http:// bankhar.org. Accessed on 9/2/2016.

Norwich, E. 2005. The Master of Game, edited by William A. Baillie-Grohman and F. N. BaillieGrohman. University of Pennsylvania Press, Philadelphia.

Plano Carpini, G. 1996. The Story of the Mongols Whom $W e$ Call the Tartars. Erik Hildinger, trans. Branden, Boston, MA.

Polo, M. 1927. The Book of Ser Marco Polo the Venetian, edited by George Parks. Henry Yule, trans. MacMillan, New York.

Roux, J. 1966. Faune et flore sacrées dans les sociétés altaïques. A. Maisonneuve, Paris.

Rubruck, W. 1990. The Mission of Friar William of Rubruck. Peter Jackson, trans. Hakluyt Society, London.

Shizhen, L. 2003. Compendium of Materia Medica (Bencao Gangmu). Luo Xiwen and the Committee for the Editing and Publication of the English Edition of Compendium of Materia Medica, trans. Foreign Languages Press, Beijing.

Sommer, M. 2015. Polyandry and Wife-selling in Qing Dynasty China. University of California Press, Berkeley.

Song, X., ed. 2000. Huibui Yaofang Kanshi (a Critical Translation of the Muslim Materia Medica). Zhonghua Shuju, Beijing.

Sowerby, Arthur de Carle. 1940. Nature in Chinese Art. John Day, New York. 